\title{
Cover crops for managing weeds, soil chemical fertility and nutritional status of organically grown orange orchard in Sicily
}

\author{
Rosario Paolo Mauro, Umberto Anastasi, Sara Lombardo, Gaetano Pandino, \\ Roberto Pesce, Alessia Restuccia, Giovanni Mauromicale \\ Dipartimento di Agricoltura, Alimentazione e Ambiente, Università di Catania, Italy
}

\begin{abstract}
Cover crops can offer significant advantages in the agronomic management of citrus orchards in Mediterranean environments. Therefore, a three-year research was conducted in eastern Sicily aimed at studying the effects of four cover crop sequences (Sinapis arvensis-Trigonella foenum-graecum-T. foenum-graecum; Medicago scutellata-Avena sativa-Lolium perenne; Vicia faba minor-A. sativa-A. sativa; A. sativa-V. faba. minor-L. perenne) on weeds, major soil chemical properties and nutritional status of an organically grown orange orchard. The results highlighted that, among the studied cover crop sequences, Vicia faba-Avena-Avena was the most beneficial for weeds control within the orchard (92\%, of cover crop cover, and 586 and $89 \mathrm{~g}$ DW $\mathrm{m}^{-2}$ of cover crop aboveground biomass and weeds aboveground biomass, respectively). Overall, the chemical fertility of the soil was positively influenced. In particular, it was observed an increase of the content of total nitrogen and available phosphorus in the soil by both Sinapis-Trigonella-Trigonella $\left(0.75 \mathrm{~g} \mathrm{~kg}^{-1}\right.$ and $59.0 \mathrm{mg} \mathrm{kg}^{-1}$, respectively) and Vicia faba-Avena-Avena $\left(0.70 \mathrm{~g} \mathrm{~kg}^{-1}\right.$ and $56.0 \mathrm{mg} \mathrm{kg}^{-1}$, respectively) cover crop sequences. Medicago-Avena-Lolium sequence seemed to be the most useful to ensure a better nutritional status of the orange orchard.
\end{abstract}

Correspondence: Umberto Anastasi, Dipartimento di Agricoltura, Alimentazione e Ambiente (Di3A), Università di Catania, via Valdisavoia 5, 95123 Catania, Italy.

Tel.: +39.095.234461 - Fax: +39.095 .234449 .

E-mail: umberto.anastasi@unict.it

Key words: Cover crops; nutritional status of trees; orange orchard; soil chemical properties; weeds.

Conference presentation: SIA XLIII Congress, Pisa, 2014.

Received for publication: 21 December 2014.

Revision received: 23 February 2015.

Accepted for publication: 23 February 2015.

CC Copyright R.P. Mauro et al., 2015

Licensee PAGEPress, Italy

Italian Journal of Agronomy 2015; 10:641

doi:10.4081/ija.2015.641

This article is distributed under the terms of the Creative Commons Attribution Noncommercial License (by-nc 3.0) which permits any noncommercial use, distribution, and reproduction in any medium, provided the original author(s) and source are credited.

\section{Introduction}

The growing concern about the negative side-effects of modern agriculture, has stimulated the need to find new agronomic solutions in order to improve the ecological profile of agrosystems (Carvalho Mendes and De Tourdonnet, 2013; Mauro et al., 2014). In this framework, cover crops can offer a valuable contribution for the agronomic management of modern agrosystems, since the positive effects that can generate on yield characteristics as well as lowering the environmental impact in farming systems (Lu et al., 2000; Djigal et al., 2012; Scopel et al., 2013). In this view, cover cropping has been proposed as a pivotal tool of improving agricultural sustainability, since in the soil it has the potential to mitigate compaction and erosion (Mitchell et al., 1999; Scopel et al., 2013), increase porosity (Carof et al., 2007), improve the ability to retain and remobilise nutrients (Doltra and Olesen, 2013), enrich organic matter content, especially in the case of legume species (Stagno et al., 2008), enhance the macrofauna activity (Blanchart et al., 2006), release non-available phosphorus (Kamh et al., 1999), stimulate the generalist predator arthropod populations and heartworm communities. Moreover, cover crops generally reduce pest and weed pressure on cash crops (Den Hollander et al., 2007; Hiltbrunner et al., 2007; Pelosi et al., 2009; Chen et al., 2011; Campiglia et al., 2012) and consequently, can also represent a key option in the agronomic management of orchards in Mediterranean-type environments (Mauromicale et al., 2010; Mauro et al., 2011, 2014). However, these beneficial functions, particularly relevant under organic and lowinput cropping regimes, require a knowledge about the adaptability of the species for the different agro-ecological conditions, with special attention about the changes that occur on native flora, soil properties and fruit trees (Mauro et al., 2013). For these reasons, a research was carried out in order to assess the effects of different cover crops sequences on weeds, major soil chemical characteristics and nutritional status of an organically grown orange orchard.

\section{Materials and methods}

A three-year experiment, from 2011-12 to 2013-14, was conducted in eastern Sicily $\left(37^{\circ} 34^{\prime}\right.$ N $14^{\circ} 54^{\prime}$ E, $225 \mathrm{~m}$ asl) within a $\sim 25$ year-old orange orchard [Citrus $\mathrm{x}$ sinensis (L.) Osbeck, cultivar Tarocco comune] grafted on a $C$. x aurantium L. rootstock organically grown, at a planting density of 400 plant ha $^{-1}(5 \times 5 \mathrm{~m}$ tree spacing). The climate of the area is Mediterranean semiarid, characterised by mild and wet winter, and warm and dry summer. The soil of the area is classified as Vertic xerofluvents according to soil taxonomy. At the start of the experiment, the soil was sampled and analysed for texture (39\% clay, $28 \%$ silt, $33 \%$ sand), macronutrients content $\left(0.55 \mathrm{~g} \mathrm{~kg}^{-1}\right.$ total $\mathrm{N}, 47.0 \mathrm{mg}$ $\mathrm{kg}^{-1} \mathrm{P}_{2} \mathrm{O}_{5}$ and $461 \mathrm{mg} \mathrm{kg}^{-1}$ exchangeable $\left.\mathrm{K}_{2} \mathrm{O}\right)$, organic matter $(9.8 \mathrm{~g}$ $\mathrm{kg}^{-1}$ ), total $\mathrm{CaCO}_{3}(9.6 \%)$ and $\mathrm{pH}(7.2)$, according to the Italian official 
methods (Italian Regulation, 1999). Therefore, the soil was clay-loam and had low level of total $\mathrm{N}$, organic matter and total Ca carbonate, and high phosphorus (P) and potassium (K) level, with carbon/nitrogen ratio $(\mathrm{C} / \mathrm{N})$ equal to 10.36 .

Throughout the three years, the following four sequences of cover crop species were implemented within the orchard:

- $\left(\mathrm{S}_{1}\right)$ Sinapis arvensis $\mathrm{L}$. (ocal landrace)-Trigonella foenum-graecum

L. (local landrace)-T. foenum-graecum L. (local landrace);

- $\left(\mathrm{S}_{2}\right)$ Medicago scutellata L. (Kelson)-Avena sativa L. (local landrace)Lolium perenne L. (Popeye);

- $\left(\mathrm{S}_{3}\right)$ Vicia faba L. subsp. minor Beck (Prothabon)-A. sativa L. (local landrace)-A. sativa L. (local landrace);

- $\left(\mathrm{S}_{4}\right)$ A. sativa L. (local landrace)-V. faba subsp. minor (Prothabon)- $L$. perenne L. (Popeye).

These treatments were attributed to experimental units of $100 \mathrm{~m}^{2}$ three times replicated and arranged according to a randomised-block design.

In each year, cover crops were hand seeded in late October at rate of 45 seeds $\mathrm{m}^{-2}$ for $V$. faba minor and 500 seeds $\mathrm{m}^{-2}$ for the other species. In late spring, when the sward reached the maximum growth and cover crops species were at the full flowering stage, the plant coverage was estimated as a proportion of soil covered by the cover crop through three independent visual assessments. Afterward, eight sampling areas of $0.25 \mathrm{~m}^{2}(0.5 \mathrm{x} 0.5 \mathrm{~m})$ randomly selected within each experimental unit were harvested cutting the sward at about $0.1 \mathrm{~m}$ above ground. For each collected sample, the cover crop species were separated from the weeds and the two components were weighed separately. These two subsamples were weighed again after drying in a thermo-ventilated oven at $105^{\circ} \mathrm{C}$ until constant weight, in order to determine their contribution in terms of dry biomass and the cover crop/weeds ratio was derived.

At the end of June 2014, ten soil samples per plot were taken by means of a $4 \mathrm{~cm}$ (i.d.) core auger to a depth of $0.3 \mathrm{~m}$, in order to evaluate the overall effects of cover crop sequences on the main soil chemical properties. The soil samples were analysed according to the Italian official methods (Italian Regulation, 1999).

For the chemical analyses of tree leaves, a representative sample (6-7 month-old) were collected at the beginning of November from the end unfruiting branch of five trees (Embleton et al., 1973). A subsample (at least 15 leaves) was immediately freeze-dried (Christ freeze drier, Osterode am Harz, Germany), ground and used for the determination of total chlorophyll content (Uddling et al., 2007). The remaining leaves

Table 1. Cover crops and weeds characteristics over the three-year experiment.

\begin{tabular}{|c|c|c|c|c|c|c|c|c|c|c|c|c|}
\hline \multirow[t]{2}{*}{ Years } & \multicolumn{4}{|c|}{$\begin{array}{c}\text { Cover crop ground cover } \\
\text { (\%) }\end{array}$} & \multicolumn{4}{|c|}{$\begin{array}{l}\text { Cover crop sequence } \\
\text { Cover crop above ground biomass } \\
\left(\mathrm{g} \mathrm{DW} \mathrm{m}^{-2}\right)\end{array}$} & \multicolumn{4}{|c|}{$\begin{array}{l}\text { Weeds aboveground biomass } \\
\qquad\left(\mathrm{g} \mathrm{DW} \mathrm{m}^{-2}\right)\end{array}$} \\
\hline & $\left(S_{1}\right)$ & $\left(S_{2}\right)$ & $\left(\mathrm{S}_{3}\right)$ & $\left(\mathrm{S}_{4}\right)$ & $\left(\mathrm{S}_{1}\right)$ & $\left(\mathrm{S}_{2}\right)$ & $\left(\mathrm{S}_{3}\right)$ & $\left(\mathrm{S}_{4}\right)$ & $\left(S_{1}\right)$ & $\left(\mathrm{S}_{2}\right)$ & $\left(\mathrm{S}_{3}\right)$ & $\left(\mathrm{S}_{4}\right)$ \\
\hline 2011-2012 & $\operatorname{Sin}$ & Med & Vic & Ave & Sin & Med & Vic & Ave & $\operatorname{Sin}$ & Med & Vic & Ave \\
\hline Means & $80^{\mathrm{b}}$ & $74^{c}$ & $89^{a}$ & $94^{\mathrm{a}}$ & $421^{c}$ & $323^{\mathrm{d}}$ & $642^{\mathrm{b}}$ & $692^{\mathrm{a}}$ & $265^{\mathrm{a}}$ & $254^{\mathrm{a}}$ & $92^{\mathrm{b}}$ & $71^{b}$ \\
\hline $2012-2013$ & $T r i$ & Ave & Ave & Vic & $T r i$ & Ave & Ave & Vic & Tri & Ave & Ave & Vic \\
\hline Means & $43^{c}$ & $94^{\mathrm{ab}}$ & $97^{a}$ & $89^{b}$ & $401^{c}$ & $540^{\mathrm{b}}$ & $577^{\mathrm{b}}$ & $653^{\mathrm{a}}$ & $211^{\mathrm{a}}$ & $118^{b}$ & $87^{c}$ & $88^{c}$ \\
\hline 2013-2014 & Tri & Lol & Ave & Lol & Tri & Lol & Ave & Lol & $T r i$ & Lol & Ave & Lol \\
\hline Means & $36^{c}$ & $28^{\mathrm{d}}$ & $91^{\mathrm{a}}$ & $50^{\mathrm{b}}$ & $327^{b}$ & $115^{\mathrm{d}}$ & $538^{a}$ & $254^{c}$ & $218^{b}$ & $202^{b}$ & $88^{c}$ & $308^{a}$ \\
\hline 3-year means & $53^{c}$ & $65^{c}$ & $92^{\mathrm{a}}$ & $77^{\mathrm{b}}$ & $383^{c}$ & $326^{\mathrm{d}}$ & $586^{\mathrm{a}}$ & $533^{b}$ & $231^{\mathrm{a}}$ & $191^{b}$ & $89^{\mathrm{d}}$ & $156^{\mathrm{c}}$ \\
\hline
\end{tabular}

Sin, Sinapis arvensis L.; Med, Medicago scutellata L.; Vic, Vicia faba L. subsp. minor Beck; Ave, Avena sativa L.; Tri, Trigonella foenum-graecum L.; Lol, Lolium perenne L. a,b,c,dWithin each year and 3-year, means followed by different letters in the same row indicate significant differences at $\mathrm{P}<0.05$ ( $F$-protected least significant difference test).

Table 2. Chemical characteristics of soil and orange tree leaves at the end of the experiment (June 2014) under the four cover crop sequences.

\begin{tabular}{|c|c|c|c|c|}
\hline Chemical constituent & $\begin{array}{c}\left(\mathrm{S}_{1}\right) \\
\text { Sin - Tri - Tri }\end{array}$ & $\begin{array}{c}\text { Cover } \\
\left(\mathrm{S}_{2}\right) \\
\text { Med - Ave - Lol }\end{array}$ & $\begin{array}{c}\left(\mathrm{S}_{3}\right) \\
V i c-A v e-A v e\end{array}$ & $\begin{array}{c}\left(\mathrm{S}_{4}\right) \\
\text { Ave - Vic - Lol }\end{array}$ \\
\hline \multicolumn{5}{|l|}{ Soil } \\
\hline Organic matter $\left(\mathrm{g} \mathrm{kg}^{-1}\right)$ & $10.3^{b}$ & $11.2^{\mathrm{ab}}$ & $12.9^{\mathrm{a}}$ & $11.2^{\mathrm{ab}}$ \\
\hline Total N $\left(\mathrm{g} \mathrm{kg}^{-1}\right)$ & $0.75^{\mathrm{a}}$ & $0.60^{\mathrm{b}}$ & $0.70^{\mathrm{ab}}$ & $0.60^{\mathrm{b}}$ \\
\hline Assimilable P $\left(\mathrm{mg} \mathrm{kg}^{-1}\right)$ & $59.0^{\mathrm{a}}$ & $42.5^{b}$ & $56.0^{\mathrm{a}}$ & $46.0^{\mathrm{b}}$ \\
\hline \multicolumn{5}{|l|}{ Orange tree leaves } \\
\hline Total chlorophyll (mg g ${ }^{-1} \mathrm{FW}$ ) & $3.0^{\mathrm{b}}$ & $3.4^{\mathrm{a}}$ & $2.6^{\mathrm{c}}$ & $2.9^{\mathrm{bc}}$ \\
\hline $\mathrm{Ca}\left(\mathrm{mg} 100 \mathrm{~g}^{-1} \mathrm{DW}\right)$ & $408^{c}$ & $658^{\mathrm{a}}$ & $486^{\mathrm{b}}$ & $503^{b}$ \\
\hline $\mathrm{K}\left(\mathrm{mg} 100 \mathrm{~g}^{-1} \mathrm{DW}\right)$ & $302^{b}$ & $311^{\mathrm{b}}$ & $335^{\mathrm{a}}$ & $326^{\mathrm{a}}$ \\
\hline $\mathrm{Mg}\left(\mathrm{mg} 100 \mathrm{~g}^{-1} \mathrm{DW}\right)$ & $88^{b}$ & $114^{\mathrm{a}}$ & $95^{\mathrm{b}}$ & $83^{c}$ \\
\hline $\mathrm{Na}\left(\mathrm{mg} 100 \mathrm{~g}^{-1} \mathrm{DW}\right)$ & $20^{\mathrm{b}}$ & $23^{\mathrm{a}}$ & $17^{c}$ & $16^{\mathrm{c}}$ \\
\hline $\mathrm{Fe}\left(\mathrm{mg} 100 \mathrm{~g}^{-1} \mathrm{DW}\right)$ & $3.6^{\mathrm{a}}$ & $2.1^{\mathrm{c}}$ & $2.1^{\mathrm{c}}$ & $2.2^{\mathrm{c}}$ \\
\hline $\operatorname{Mn}\left(\mathrm{mg} 100 \mathrm{~g}^{-1} \mathrm{DW}\right)$ & $0.23^{\mathrm{a}}$ & $0.17^{c}$ & $0.24^{\mathrm{a}}$ & $0.19^{b}$ \\
\hline $\mathrm{Cu}\left(\mathrm{mg} 100 \mathrm{~g}^{-1} \mathrm{DW}\right)$ & $0.23^{\mathrm{a}}$ & $0.24^{\mathrm{a}}$ & $0.17^{\mathrm{a}}$ & $0.23^{\mathrm{a}}$ \\
\hline
\end{tabular}

Sin, Sinapis arvensis L.; Tri, Trigonella foenum-graecum L.; Med, Medicago scutellata L.; Vic, Vicia faba L. subsp. minor Beck; Ave, Avena sativa L.; Lol, Lolium perenne L; N, nitrogen; P, phosphorus; Ca, calcium; K, potassium; Mg, magnesium; Na, sodium; Fe, iron; Mn, manganese; $\mathrm{Cu}$, copper. a,b,cValues followed by different letters in each row indicate significant differences at $\mathrm{P}<0.05$ ( $F$-protected least significant difference test). 
were oven-dried at $65^{\circ} \mathrm{C}$ (Binder, Milan, Italy) until a constant weight was reached. Then, the dehydrated material was ground and used for the determination of mineral profile according to the AOAC official method (1995). All the reagents and solvents, of analytical or high-performance liquid chromatography grade, were purchased from Sigma-Aldrich (Milan, Italy). All the chemical analyses were performed in triplicate.

Shapiro-Wilk's and Levene's tests were used to assess preliminarily the data for normal distribution and homoscedasticity, respectively, and the one-way ANOVA $(\mathrm{P} \leq 0.05)$ was applied. Percentage data were Bliss' transformed before the ANOVA (untransformed data are reported). Multiple mean comparisons were performed through Fisher's protected least significant difference test $(\mathrm{P} \leq 0.05)$.

\section{Results and discussion}

Among the tested cover crop sequences, on average of the three years, $\mathrm{S}_{3}$ (Vicia faba-Avena-Avena) highlighted the highest degree of ground cover as well as the greater amount of aboveground biomass, although the latter over the three years has not always been significantly higher, since in the first two years it has been higher for $\mathrm{S}_{4}$ (Avena-Vicia faba-Lolium) (Table 1). By contrast, regardless the years, a significantly higher amount of weeds biomass were achieved for $\mathrm{S}_{1}$ (Sinapis-Trigonella-Trigonella) followed by $\mathrm{S}_{2}$ (Medicago-AvenaLolium). Consequently, irrespective of the years, also the cover crops/weeds ratio, as a simple index of competitive ability of cover crops against weeds, was higher for $S_{3}$ and $S_{4}$ (6.6 and 6.0, respectively) compared to that found for S1 and S2 (1.7 and 2.1, respectively) (data not shown). Among the studied plant species, overall, the more competitive against weeds were oat within the Poaceae and field bean within the Fabaceae (Campiglia et al., 2012; Mauro et al., 2013). The same two plant species appear to have ensured a better degree of complementarity in $S_{3}$ cover crop sequence.

The analysis of the main chemical characteristics of the soil revealed overall an enhancement passing from the start to the end of the experiment, except that for assimilable phosphorus as a result of $S_{2}$ and $S_{4}$ treatments (Table 2). Nevertheless, the differences between the cover crop sequences were not always significant (Stagno et al., 2008). In particular, organic matter level was greater for $\mathrm{S}_{3}$ compared to that of $S_{1}$, which anyway not differed from that observed for $S_{2}$ and $S_{4}$. However, the values of the latter two treatments were statistically similar to that of $\mathrm{S}_{3}$ as well. The content of total nitrogen was significantly higher for $S_{1}$ and $S_{3}$, but the value observed for the latter treatment not differed statistically from those of the other ones. Assimilable P was found significantly higher for both $S_{1}$ and $S_{3}$ compared to the other cover crop sequences (Doltra and Olesen, 2013). The $\mathrm{C} / \mathrm{N}$ ratio, which was equal to 10.36 at the start of the experiment decreased only for $S_{1}$ (7.50), in which two years of Trigonella followed one year of Sinapis, as compared to the other cover crop sequences (10.79, on average), which instead, led to a slight increase of this index (data not shown).

Leaf analysis, although limited to the end of the three-years of trials, allowed assessing the differences in the nutritional status of the orange trees in relation to the cover crop sequences. $S_{2}$ lead to the highest content of total chlorophyll in the leaves of trees. There are little knowledge concerning the variability of mineral composition of orange tree leaves in relation to different environmental and agronomic conditions, and specific information about Tarocco comune cultivar grown in Sicily under organic regime are unavailable. Therefore, for a comparison of our results of trees nutritional status we considered as source the reference values (deficient, low, optimal, high and excessive) of average concentrations of macro and micronutrients reported for the orange orchard by Embleton et al. (1973). According to these
Authors, our data highlighted, overall, a critical nutritional status of the orchard, because the concentration of the minerals analysed was found below the threshold of deficiency. However, adopting $S_{2}$ cover crop sequence the highest mineral content of $\mathrm{Ca}, \mathrm{Mg}$ and $\mathrm{Na}$ was reached, whereas $S_{3}$ and $S_{4}$ lead to a higher content of $K$ in the leaves. $S_{1}$, instead, resulted in a higher content of $\mathrm{Fe}$ and $\mathrm{Mn}$ in the tree leaves, although the latter element was found similar to $S_{3}$. The four studied cover crop sequences similarly affected the $\mathrm{Cu}$ content of tree leaves.

Based on the findings obtained by this research, which require further confirmation, it can be argued that, in the organically grown orange orchard under the eastern Sicilian environmental conditions, among the different sequences of cover crop studied, Vicia faba-AvenaAvena was the most effective in terms of ground cover and weeds control. Overall, the chemical fertility of the soil was positively influenced, although not univocally related to the cover crop sequences, which with the exception of the Sinapis-Trigonella-Trigonella, have contributed to maintain an optimal $\mathrm{C} / \mathrm{N}$ ratio. However, it is also worth mentioning the tendency toward an increase of the content of total nitrogen and available phosphorus in the soil by the two cover crop sequences Sinapis-Trigonella-Trigonella and Vicia faba-Avena-Avena. Moreover, the sequence Medicago-Avena-Lolium, despite the conditions of general nutritional deficiency observed in the orange orchard, seemed to be the most appropriate to ensure a better status of the trees.

\section{References}

AOAC, 1995. Official method 975.03: metals in plants. $16^{\text {th }}$ ed. The Association of Official Analytical Chemists, Arlington, VA, USA.

Blanchart E, Villenave C, Viallatoux A, Barthès B, Girardin C, Azontonde A, Feller C, 2006. Long-term effect of a legume cover crop (Mucunapruriens var. utilis) on the communities of soil macrofauna and nematofauna, under maize cultivation, in southern Benin. Eur. J. Soil Biol. 42:S136-44.

Campiglia E, Radicetti E, Mancinelli R, 2012. Weed control strategies and yield response in a pepper crop (Capsicum annuum L.) mulched with hairy vetch (Vicia villosa Roth.) and oat (Avena sativa L.) residues. Crop Prot. 33:65-73.

Carof M, De Tourdonnet S, Coquet Y, Hallaire V, Roger-Estrade J, 2007. Hydraulic conductivity and porosity under conventional and notillage and the effect of three species of cover crop in Northern France. Soil Use Manage. 23:230-7.

Carvalho Mendes I, De Tourdonnet S, 2013. Conservation agriculture cropping systems in temperate and tropical conditions, performances and impacts. A review. Agron. Sustain. Develop. 33:113-30.

Chen LL, You MS, Chen SB, 2011. Effects of cover crops on spider communities in tea plantations. Biol. Control 59:326-35.

Den Hollander NG, Bastiaans L, Kropff MJ, 2007. Clover as a cover crop for weed suppression in an intercropping design I. Characteristics of several clover species. Eur. J. Agron. 26:92-103.

Djigal D, Saj S, Rabary B, Blanchart E, Villenave C, 2012. Mulch type affects soil biological functioning and crop yield of conservation agriculture systems in a long-term experiment in Madagascar. Soil Till. Res. 118:11-21.

Doltra J, Olesen JE, 2013. The role of catch crops in the ecological intensification of spring cereals in organic farming under Nordic climate. Eur. J. Agron. 44:98-108.

Embleton TW, Reitz HJ, Jones WW, 1973. Citrus fertilization. In: W. Reuther (ed.), The citrus industry, Vol. III Revised ed. University of California Press, Berkeley, CA, USA, pp 122-182.

Hiltbrunner J, Liedgens M, Bloch L, Stamp P, Streit B, 2007. Legume cover crops as living mulches for winter wheat: components of bio- 
mass and the control of weeds. Eur. J. Agron. 26:21-9.

Italian Regulation, 1999. Ministero delle Politiche Agricole e Forestali Decreto Ministeriale 13 settembre 1999 n. 185. Approvazione dei Metodi ufficiali di analisi chimica del suolo. In: G.U. n. 248, 21/10/1999.

Kamh M, Horst WJ, Amer F, Mostafa H, Maier P, 1999. Mobilization of soil and fertilizer phosphate by cover crops. Plant Soil 211:19-27.

Lu YC, Watkins KB, Teasdale JR, Abdul-Baki AA, 2000. Cover crops in sustainable food production. Food Rev. Int. 16:121-57.

Mauro RP, Pesce GR, Mauromicale G, 2013. The role of cover crops in agro-ecosystems management. In: A. Taab (ed.), Weeds and their ecological functions. Nova Science Publishers, Inc., Hauppauge, New York, NY, USA, pp 115-152.

Mauro RP, Occhipinti A, Longo AMG, Mauromicale G, 2011. Effects of shading on chlorophyll content, chlorophyll fluorescence and photosynthesis of subterranean clover. J. Agron. Crop Sci. 197:57-66.

Mauro RP, Sortino 0, Dipasquale M, Mauromicale G, 2014. Phenological and growth response of legume cover crops to shading. J. Agric. Sci. 152:917-31.
Mauromicale G, Occhipinti A, Mauro R, 2010. Selection of shade-adapted subterranean clover species for cover cropping in orchards. Agron. Sustain. Develop. 30:473-80.

Mitchell JP, Thomsen CD, Graves WL, Shennan C, 1999. Cover crops for saline soils. J. Agron. Crop Sci. 183:167-78.

Pelosi C, Bertrand M, Roger-Estrade J, 2009. Earthworm community in conventional, organic and direct seeding with living mulch cropping systems. Agron. Sustain. Develop. 29:287-95.

Scopel E, Triomphe B, Affholder F, Macena Da Silva FA, Corbeels M, Valadares Xavier JH, Lahmar R, Recous S, Bernoux M, Blanchart E, De Carvalho Mendes I, De Tourdonnet S, 2013. Conservation agriculture cropping systems in temperate and tropical conditions, performances and impacts. A review. Agron. Sustain. Develop. 33:113-30.

Stagno F, Abbate C, Intrigliolo F, Abbate V, Gennari M, 2008. Effect of leguminous cover crops on soil biological activity in pots of Citrus unshiu Marcovitch. Ital. J. Agron. 3:183-90.

Uddling J, Gelang-Alfredsson J, Piikki K, Pleijel H, 2007. Evaluating the relationship between leaf chlorophyll concentration and SPAD-502 chlorophyll meter readings. Photosynth. Res. 91:37-46. 